\title{
Of Solitude, Skepticism, and Subjectivity: Michel de Montaigne's poêle in La Villa
}

\author{
SCOTT D. JUALL \\ University of North Carolina Wilmington
}

Cet article examine les expériences de solitude de Michel de Montaigne aux bains de La Villa dépeintes dans le Journal de voyage en Italie (1580-1581), ouvrage autobiographique portant en grande partie sur les épreuves de l'écrivain devenu voyageur en essayant de se guérir d'un cas sérieux et chronique de calculs rénaux. Les remèdes futiles que Montaigne cherche sans cesse pendant ses séjours à La Villa et les effets sur son esprit qui en résultent jouent un rôle d'une importance capitale dans le développement de sa conception du scepticisme à l'égard de la médecine, préalablement décrit dans les essais "Apologie de Raimond Sebond" (II, 12) et surtout "De la ressemblance des enfants aux peres" (II, 37). Cette analyse, qui procède donc d'un point de vue philosophique ainsi que littéraire, considère en particulier le rôle du rapport entre la solitude, le scepticisme à l'égard de la médecine - ancienne aussi bien que contemporaine —, l'empirisme, et l'ontologie de Montaigne dans l'établissement de la subjectivité proto-, voire méta-cartésienne, au seuil de la modernité.

$\mathrm{T}$ heorists have long acknowledged that René Descartes' revelations in the poêle marked a significant step in the development of modern thought. Widely considered the founder of modern philosophy, Descartes made unique statements on the human as an individual thinking entity while developing a method for finding certainty of truth. We are all familiar with Descartes' unshakeable principle "je pense, donc je suis," his first foundation of metaphysics frequently referred to as the cogito — regarded today as the basis of modern subjectivity—, as well as his mind/ body dualism and proof of the existence of God and the soul. Scholars of philosophy and literary criticism such as Hassan Melehy have compared representations of the self in Descartes' œuvre with that in Michel de Montaigne's Essais in particular, concluding that the sixteenth-century essayist is somewhat distant from attaining the seventeenth-century philosopher's status as a modern subject. ${ }^{1}$ Melehy argues that because of Montaigne's inconstant thought, numerous and changing perspectives, non-chronological writing, and frequent additions to the Essais, his writing reflects a fragmented, decentred subject—one that is "anything but an integral, self-

Renaissance and Reformation / Renaissance et Réforme 30.2, Spring/printemps 2006 
100 SCOTT D. JUALL

contained unity $[\ldots]$ this subject knows itself as plural, multiple, and this knowing is reached in the writing of the book." 2 By contrast, through his cogito formulated in the poêle, Descartes arrives at the conclusion that there is no doubt that he thinks and, as a result, that he must exist. Building upon this assertion, Descartes draws directly from Montaigne's Essais to aspire to write a text that, Melehy asserts, will "present itself as a unity [...] that may be narrated by a single subject" - one that is written by "a fixed subject that would, from its firmly installed position, control the production of writing." 3

Here I would like to broaden the comparison of these two great French thinkers through an analysis of Montaigne's Journal de voyage en Italie (1580-81), which offers additional insight into the question of subjectivity in the essayist turned traveller. In the Journal de voyage, Montaigne describes his experiences of self-imposed solitude that present a break in physical movement and greatly limit exposure to external stimuli-a situation not at all unlike Descartes' famous visit to the poêle in 1619. Although their motives for spending time alone are different, both writers actively seek out a solution to a particular problem during their isolation from others. By means of his experiences of solitude, Montaigne attempts to find a cure for his kidney stones during two prolonged stays at the baths of La Villa in Italy. There he puts into practice certain approaches to medical treatment and develops his already established theories of empirical skepticism, both of which he records in the Journal de voyage and in certain Essais. Some 40 years later, Descartes spends time in the poêle in Germany with the aim of discovering a method to finding truth. Descartes' cogito inspires him to put his thought to the test through life experiences in the real world. His travels are followed by a long period of solitude and focused meditation in order to draw conclusions, organize his thoughts, and write them down systematically. Descartes, as Montaigne before him, keeps a record of his experience of solitude, its effects on his thinking, and the influence that they exert on his subjective and ontological formulations; his earliest metaphysical writings, Discours de la méthode (1637) and Méditations métaphysiques (1641), have long been celebrated for establishing the essential bases of modern philosophy.

The experiences of solitary meditation of Montaigne and Descartes are not only remarkably analogous; I maintain that the results of spending time alone for these two thinkers during a period of self-imposed exile are strikingly similar. While the question of Montaigne's place in the development of subjectivity has been frequently addressed by numerous exegetical inquiries into the Essais, I contend that Montaigne makes crucial observations on subjectivity and being in the Journal de voyage and in the Essais hitherto unexamined and, moreover, that the essayist's 
meditations while travelling reveal a significant step in the foundation of modern thought. Here I investigate Montaigne's experiences of solitude during his two stays in La Villa and, more precisely, his philosophy of medical skepticism tested there, topics that have received surprisingly little scholarly attention. ${ }^{4} \mathrm{My}$ aim is to shed additional light on the relationship between solitude, skepticism, and subjectivity in some of Montaigne's writings and to analyze his role in the development of the early modern physical and metaphysical journey of self-discovery.

\section{Montaigne's skepticism of medicine in 1580: essays II, 12 and II, 37}

Before setting out on his voyage through parts of Western Europe in the fall of 1580 , Montaigne had already developed observations on skepticism of medical practices in essay II, 12, "Apologie de Raimond Sebond," and most notably in an extended development of the topic in essay II, 37, "De la ressemblance des enfants aux peres"-both of which appeared in print earlier that same year. ${ }^{5}$ In the "Apologie," as part of his broader Pyrrhonian skepticism treated expressly throughout in the essay, ${ }^{6}$ Montaigne states that he mistrusts a variety of recent doctrinal developments in a number of areas, generating a deliberately skeptical attitude toward contemporary scientific pretensions in general—including a brief commentary on medicine. ${ }^{7}$ Because of the sustained focus on such topics on the part of Montaigne, theorists such as Richard Henry Popkin have argued that the crisis of scientific knowledge-more than the theological crisis related to the problem of the rule of faith and the humanist crisis of knowledge brought on by the rediscovery of ancient thought-is precisely the "most significant skeptical crisis precipitated by Montaigne" in the "Apologie":

Montaigne's last series of doubts, the most philosophical level of his Pyrrhonism, raised a whole series of problems, about the reliability of sense knowledge, the truth of first principles, the criterion of rational knowledge, our inability to know anything except appearances, and our lack of any certain evidence or nature of the real world. These problems, when seriously considered, undermined confidence in man's ability to discover any science in Aristotle's sense-truths about the world that are certain. ${ }^{8}$

In "De la ressemblance," Montaigne treats skepticism in relation to medical practices much more explicitly. In this essay, he generates what Andrea Carlino calls "a merciless critique of medicine," 9 which he derives from a number of textual authorities_-ancient and contemporary—enlisted to support his arguments against both medicine and the "perpetuel desaccord qui se trouve és opinions des principaux maistres et autheurs anciens de cette science." ${ }^{10}$ Montaigne puts less trust 
in the authority of contemporary medical theorists such as Paracelsus, Fioraventi, and Argenterius than in the wisdom of the Ancients medical authorities such as Hierophilus, Asclepiades, Alcmaeon, Diocles, Strato, and Hippocrates who, despite their superior knowledge, Montaigne argues, came no closer to a consensus on helpful medical treatments than early modern doctors. ${ }^{11}$ The essayist is particularly skeptical of "toute cette diversité et confusion d'ordonnances," ${ }^{12}$ which either worsen an illness or have absolutely no effect more often than help the patient improve an ailment. Montaigne addresses this problem directly, demanding that doctors excuse his liberty in criticizing their profession since his ancestors, who also suffered from kidney stones, possessed good health and lived to an old age as a direct result of not seeking medical treatment from them:

Que les medecins excusent un peu ma liberté, car, par cette mesme infusion et insinuation fatale, j'ay receu la haine et le mespris de leur doctrine: cette antipathie que j'ay à leur art, m'est hereditaire. Mon pere a vescu soixante et quatorze ans, mon ayeul soixante et neuf, mon bisayeul pres de quatre vingts, sans avoir gousté aucune sorte de medecine; et, entre eux, tout ce qui n'estoit de l'usage ordinaire, tenoit lieu de drogue. [...] Mes ancetres avoient la medecine à contre cœur par quelque inclination occulte et naturelle: car la veuë mesme des drogues faisoit horreur a mon pere. ${ }^{13}$

Based on his own attempts to cure his gravelle and his lack of finding successful remedies, Montaigne focuses repeatedly on the importance of empirical skepticism by stressing that one should rely solely on personal experience in seeking out medical cures: "La medecine se forme par exemples et experience; aussi fait mon opinion. Voylà pas une bien expresse experience et bien advantageuse?"14 The essayist also emphasizes the direct link between his concept of philosophy and approaches to suffering physical ailments:

Au demourant, j'ay tousjours trouvé ce precepte ceremonieux, qui ordonne si rigoureusement et exactement de tenir bonne contenance et un maintien desdaigneux et posé à la tollerance des maux. Pourquoy la philosophie, qui ne regarde que le vif et les effects, se va elle amusant à ces apparences externes? [...] Elle nous dresse pour nous, non pour autruy; pour estre, non pour sembler. ${ }^{15}$

Montaigne's philosophical theory thus links his conceptions of ontology and subjectivity with his bodily health. In this connection, Carlino makes the extraordinary argument that Montaigne's experience as a being who suffers from serious and chronic kidney stones - and his deep meditation on his fruitless quest to cure themshould be considered the starting point of his entire philosophical credo. ${ }^{16}$ Thus in essay II, 37, Carlino maintains, Montaigne "combines a formalized philosophical 
position with his personal views and experiences, and conveys a sort of Pyrrhonism which is embodied into the subjective experience of the suffering self." ${ }^{17}$

\section{Solitude and suffering in La Villa}

While the Essais provide useful glimpses into Montaigne's general theory of medical skepticism, the Journal de voyage demonstrates a much more thorough development of the writer's perspectives on the topic. Montaigne seeks out medical treatments for his kidney stones intermittently throughout his European travels in 1580-1581, but his experiences of subjectivity while suffering and his skepticism towards medicine are most clearly demonstrated during his two lengthy visits to La Villa in $1581 .^{18}$ The sole purpose of Montaigne's extended stays at this Italian spa town-lasting a total of nearly three months - is to gain access to a cure for his ailments at the healing baths there. Since solitude was a necessary requirement for those adhering to Pyrrhonian skepticism ever since Antiquity, La Villa's isolated location provides Montaigne with an ideal atmosphere in which to carry out a sort of experiment to test his theories of medical treatment stated one year earlier in "De la ressemblance." La Villa is also a renowned centre of medical authority, and Montaigne remarks of the town's permanent residents that "quasi tous sont apothicaires."19 His first stay in La Villa occurs during the off-season, a situation which greatly increases his interactions with local doctors and limits his contact with other visitors to the spa town. ${ }^{20}$ Furthermore, Montaigne remains almost entirely by himself and physically in place-practices that are highly contrary to his preferred approaches to travel. Since he dismissed his secretary months earlier in Rome, Montaigne alone writes all of the journal's entries recording the stay in La Villa. ${ }^{21}$ Instead of focusing on the external world around him, therefore, he meditates inwardly during this period of solitude.

One might consider the essayist's "librairie" in Montaigne as a prototype of Descartes' poêle — the privileged place for systematizing thought—-since it is in his tower that Montaigne meditates deeply on knowledge gleaned from the books in his collection, many of which his closest friend Etienne de la Boétie had left to him upon his death, and develops his ideas and approaches to thinking. However, it is precisely because of the essayist's busy domestic activities that George Hoffmann sharply contrasts the spaces of the château de Montaigne with the isolation of Descartes' poêle:

Unlike Descartes's closed, stove-heated room which afforded no view of the outside, looking out of windows constituted the very purpose of Montaigne's tower study. 
Whereas Descartes's space for reflection was turned resolutely away from the lives of others, Montaigne's was wholly turned toward them; and if Descartes's mental universe begins with the rejection of experience in a world at large, Montaigne's remained oriented toward daily interaction with the farm for which he was responsible. ${ }^{22}$

By writing in the spaces of his busy estate, therefore, Montaigne could not have arrived at the kind of ontological and subjective observations that he would make during his stays in La Villa. It is for this reason that Montaigne's experiences of solitude in the Italian spa town are such an integral part of the development of his thought. The lack of movement and static existence in such an environment almost totally void of intellectual and cross-cultural stimuli-and distant from his books and domestic responsibilities in Montaigne-influence the traveller greatly. ${ }^{23} \mathrm{He}$ all but entirely eliminates the kinds of discursive-and excursive-descriptions of people and places, stories and histories, and habits and customs that dominate the majority of the entries in the Journal de voyage and that make the work such a rich early modern ethnography of Western Europe. Montaigne's peculiar lifestyle in La Villa therefore generates a radical and immediately discernible change in the form and content of the Journal de voyage — one that leads François Rigolot to term large portions of the work "un journal de santé." ${ }^{4}$

Because the text is a jour-nal, the narrative advances, sometimes for several pages in a row, in a strictly sequential order following only the progression of Montaigne's health as the days pass. The entries focus almost entirely on the ailing self and the remedies that the traveller essays somewhat systematically_-reflecting what Alain Milon calls "une sorte d'écriture symptômatique" of illness: ${ }^{25}$

Le mardi, neuf de Mai 1581, bon matin, avant le soleil levé, j'allay boire du surgeon mesme de nostre fontaine chaude. Et en beus sept verres tout de suite, qui tiennent trois livres et demie: ils mesurent ainsi. Je croy que ce seroit à douze, nostre carton. C'est une eau chaude fort moderement, comme celle d'Aigues Caudes ou Barbotan, ayant moins de goust et saveur que nulle autre que j'aye jamais beu. Je n'y peus apercevoir que sa tiedeur et un peu de douceur. Pour ce jour elle ne me fit nulle operation, et si fus cinq heures depuis boire jusques au disner, et n'en rendis une seule goutte. Aucuns disoient que j'en avoy prins trop peu, car là ils en ordonnent un fiasque: sont deux bocals, qui sont huict livres, seize ou dix sept verres des miens. Moy je pense qu'elle me trouva si vuide, à cause de ma medecine, qu'elle trouva place à me servir d'aliment. [...]

Mercredi bon matin, je rebeus de cette eau, et estant en grand'peine du peu d'operation que j'en avoy senti le jour avant; car j'avoy bien fait une selle soudain après l'avoir prinse, mais je rendois cela à la medecine du jour precedent, n'ayant fait pas une goutte d'eau qui retirast à celle du bain. J'en prins, le mercredi, sept verres mesurés à la livre, 
qui fut pour le moins double [de] ce que j'en avoy prins l'autre jour, et croy que je n'en ay jamais tant prins en un coup. J'en sentis un grand desir de suer, auquel je ne voulsis nullement aider, ayant souvent ouï dire que ce n'estoit pas l'effect qu'il me falloit; et, comme le premier jour, me contins en ma chambre, tantost me proumenant, tantost en repos. L'eau s'achemina plus par le derriere, et me fit faire plusieurs selles lasches et claires, sans aucun effort. Je tiens qu'il me fit mal de prendre cette purgation de casse, car l'eau trouvant nature acheminée par le derriere et provoquée, suivit ce train là, là où je l'eusse, à cause de mes reins, plus desirée par le devant; et suis d'opinion, au premier bain que je prendray, de seulement me preparer avec quelque jeusne le jour avant. Aussi croy-je que cette eau soit fort lasche et de peu d'operation, et par consequent sure et point de hasard: les apprentis et delicats y seront bons. [... $]^{26}$

These intensely self-reflective entries demonstrate a stunningly modern sense of subjectivity that exemplifies, as Jean Céard states, "l'idée féconde (et moderne) selon laquelle le patient ne se contente pas d'avoir une maladie, qu'il est malade." 27 The most striking change in form and content of the Journal de voyage thus corresponds to the most intense and sustained focus on the self. The dramatically transformed thematic, stylistic, and formal qualities of the entries reporting Montaigne's stay in La Villa reflect a marked linearity of time and a strict order scarcely seen elsewhere in the travel journal. In this respect, the linear form and teleological orientation of the entries recording Montaigne's health in the Journal de voyage are in strict opposition to writing in the Essais, where, Melehy argues, "The inscriptions [...] are a disruption to the linear time that would be a prerequisite of autobiographical representation, and of the unitary subject that would take shape therein, that would be represented." 28 The highly subjective focus that Montaigne uses to describe his illness in the Journal de voyage generates the sort of ordered autobiographical thought that Descartes writes in Discours de la méthode. Certain passages in Montaigne's travel narrative thus reflect what Melehy remarks of the "teleological construction of Descartes's autobiography" - the "strictly logical sequence in which the ideas of modern philosophy may be developed."29

The pages of the Journal de voyage where Montaigne makes explicit observations on medicine in La Villa are replete with exceedingly precise medical and physiological measurements as he puts various treatments to the test. While clearly quite crude compared with today's controlled clinical trials, Montaigne presents a relatively scientific method to his examinations - particularly for his day. ${ }^{\circ}$ Many of the entries recording his symptoms, medical treatments, and reactions to cures during his stays in La Villa therefore display an attempt at highly systematic measuring, thinking, and writing. This process allows Montaigne to develop a particular approach to his trials - a method upon which he may build his skeptical philosophy of medicine. 
106 SCOTT D. JUALL

\section{Medical skepticism in La Villa: assaying treatment}

Even before setting out on his voyage, Montaigne understood the importance of experience and the development of an experimental method in putting theories of medicine to the test, as numerous statements in "De la ressemblance" suggest. It is in the journal's entries describing the stays in La Villa that we discern a distinct development in Montaigne's attitudes and approaches towards medicine as the essayist turned assayer examines medical treatments in an attempt to determine their efficaciousness. Montaigne's aim is to test all of the treatments at the baths, an approach that reflects his extreme willingness to test prescribed cures - as well as self-made remedies_-in an effort to eliminate his kidney stones. Montaigne is looking for a real, practical solution to his illness - he does not deliberately wish to remain in complete uncertainty. In this sense, by developing his doubts through reasoning and a sincere effort at finding certainty, Montaigne is closer to Descartes' approach to drawing definitive conclusions than the skepticism of sixteenth-century France's nouveaux pyrrhoniens. As Popkin states of Descartes:

As far as he could see they [nouveaux pyrrhoniens] had accomplished nothing with their doubts, and had accomplished nothing only because they had deliberately wished to remain in complete uncertainty. [...] The nouveaux pyrrhoniens might insist that they were being misrepresented, since their aim, too, was to find certain knowledge. But they hoped to find it miraculously, to have it suddenly delivered to them by God. Descartes, on the other hand, expected to locate the fundamental and indubitable truths, the foundations of human knowledge, within the mind, buried or hidden under the debris of prejudices and opinions. He expected to locate these by the very process of doubting, and not by a deus ex machina after doubting. The sceptics did not believe we were in possession of any truths, while Descartes was convinced that we were, but were also unable to see them. By doubting and negating, those opinions and beliefs that at present blind us, he said, could be removed so that truth would shine forth. ${ }^{31}$

Montaigne's approach to finding certain knowledge thus anticipates a Cartesian aim at establishing certainty-one that proves crucial to the essayist's development of ontology and subjectivity.

While Montaigne spends much time alone in La Villa, he continues to have intermittent interactions with others-primarily doctors, with whom he engages extensively in discussions related to health and medical treatments at the mineral spas. This particular situation works to Montaigne's advantage, as the constant interplay between isolation and self-study, on the one hand, and discourse with others about medical treatments, on the other, allows him to test and refine his 
knowledge of medical practices as he essays different cures. Montaigne's method thus allows him to challenge medical knowledge of contemporary doctors and what he considers "les controverses et inconstances de jugement qu' ils nourrissent et continuent entre eux." ${ }^{2}$

As Montaigne continues testing various treatments for his kidney stones, he more frequently turns away from what doctors prescribe to him, and declarations that he treats himself "contre les regles de cette contrée" 33 or "contre l'opinion commune du lieu" 34 begin to fill the pages of the travel journal. As the narrative proceeds, Montaigne emphasizes the lack of progress that he makes in determining any certainty in medical treatment. His regularly worsening physical condition and inability to determine any positive effects from prescribed cures lead to complete uncertainty regarding contemporary medical practice. With time, he makes statements such as "C'est une sotte coustume de compter ce qu'on pisse" 35 and "La vaine chose que c'est que la medecine!" ${ }^{6}$ Montaigne's medical skepticism eventually leads him to the conclusion that the cures that he seeks in La Villa are entirely futile: "Moy, si je juge bien de ces eaux, elle ne sont ny pour nuire beaucoup, ny pour servir: ce n'est que lascheté et foiblesse, et est à craindre qu'elles eschauffent plus les reins qu'elle ne les purgent; et croy qu' $i$ me faut des eaux plus chaudes et aperitives." 37

Montaigne thus sets himself apart from presumed medical authority-both ancient and contemporary. He states that what is of primary importance in developing his unique, independent theory of medical skepticism is resisting the authority of others, especially concerning the establishment of a method that will lead to independent reasoning. Consequently, Montaigne becomes a medical authority in his own right. During his first stay in La Villa, several doctors come to admire his expertise in medicine and begin to consult him for advice on treatments for their patients — and for themselves. ${ }^{38}$ Melehy makes a similar observation on Descartes' authority and autonomy of thought in the establishment of his method: "what is most important is resisting the authority of others, particularly with regard to the proper study of the method in which one will achieve an autonomy of reason." 39 Montaigne concludes that doctors fail to recognize the crucial notion that diverse theories of medicine contradict each other because humans_-as doctor or patient—are so dissimilar. ${ }^{40}$ As a result, Montaigne is led to believe that each person is a unique biological entity that requires peculiar treatments for illness. ${ }^{41}$ As Donald Frame argues, the aspects of Montaigne's vision that develop the most during his travels through Europe are on the theme of unity and diversity and the increased tension between the essayist's concept of himself and others. ${ }^{42}$ Montaigne's experiences while voyaging therefore lead him to recognize his own particular situation as he 
108 SCOTT D. JUALL

visits the baths and encounters an immensely diverse variety of customs related to medical treatment.

With this realization, while Montaigne is incapable of considering himself entirely outside of the group of bathers who frequent spas such as La Villa, he nevertheless holds a unique place among them. Montaigne's skeptical approach to medicine leads him both to identify himself with those seeking a cure and to affirm his difference from that group, revealing what Timothy Hampton identifies as "the tension between group identity and individuality that plagues discussions of subjectivity after the Renaissance" with the advent of Cartesian thought in the seventeenth century. ${ }^{43}$ Montaigne's capacity to see himself in opposition to established, conventional systems of belief and cultural practices by pursuing his own philosophy and method of medical treatment places him in an exceptional position in relation to others. This rapport establishes a tension between Montaigne and alterity, which heightens his sense of subjectivity all the more. I maintain therefore that Montaigne's observations in La Villa reveal a problematic location of the subject that is more similar to modern notions of subjectivity_-such as that beginning with Descartes - than previously argued in studies of Montaignian subjectivity. ${ }^{44}$

\section{Reflections on friendship and death: suffering and rethinking illness}

Montaigne makes explicit statements in the Essais that demonstrate that he is acutely aware of the dynamic effect that the mind and the body have on each other; moreover, he is particularly critical of philosophers who use mind/body dualism to justify a denial of the influence of corporeal experiences on the mind. ${ }^{45}$ In order to support his argument for Montaigne's central role in the foundation of modernity, Stephen Toulmin asserts that unlike his contemporaries, "Montaigne is scornful about attempts to separate mental activities from bodily changes." ${ }^{6}$ In the Journal de voyage, Montaigne records a crucial experience that describes the dynamic interaction between mind and body. In La Villa, as Montaigne's treatments of his kidney stones continue to fail at ameliorating his condition, his mental state is strongly affected. While in the Italian spa town, Montaigne records in his journal a painful experience that he had earlier while writing to Arnaud d'Ossat, French diplomat, writer, and Cardinal of the Roman Catholic church based at the French embassy in Rome. ${ }^{47}$ In this entry, Montaigne makes a remarkable statement on thinking:

Le jeudi matin, j'en rebeus cinq livres, craignant d'en estre mal servi et ne les vuider. Elles me firent faire une selle, uriner fort peu. Et, ce mesme matin, escrivant à $\mathrm{M}$. 
Ossat, je tombay en un pensement si penible de M. de la Boetie, et y fus si longtemps sans me raviser, que cela me fit grand mal. ${ }^{48}$

By writing in his journal about an earlier painful writing session, Montaigne's depicts his physical and mental state through a sort of mise-en-abime that introduces a heightened sense of self awareness. Montaigne's failed corporeal cures thus lead him directly from thinking and writing about his failing physical state to a certain thought—a "pensement" - about his compromised mental state. In describing this experience, Montaigne implicitly draws a parallel between physical healing and thinking in the homonymic - and homographic - connection between the two actions, as the term "pensement," with a single spelling and pronunciation, represented both meanings in the sixteenth century. ${ }^{49}$ Therefore, as in La Villa, where the intended treatments fail to improve — and sometimes even worsen-Montaigne's physical health, the thought of his closest friend La Boétie, who, appropriately enough, had died of a misdiagnosed case of dysentery eighteen years earlier, ${ }^{50}$ leads the traveller to a more melancholic state and serious mental anguish — what Milon describes as a sort of "mise à jour de sa souffrance." 51

Montaigne thus clearly approaches his mind through his body. As a result of his failing physical state, his "pensement"—as either thought or cure—does not calm or ease his mind or soul. Montaigne emphasizes the crucial role that judgment should normally play in attenuating his mental sufferings:

Les souffrances qui nous touchent simplement par l'ame, m'affligent beaucoup moins qu'elle ne font la pluspart des autres hommes; partie par jugement (car le nombre estime plusieurs choses horribles, ou evitables au pris de la vie, qui me sont à peu pres indifferentes) $[\ldots] .{ }^{\prime 2}$

The important relationship between judgment and medicinal cures for Montaigne has been observed by David E. Johnson, who states: "The model he follows for judgment-and for Montaigne the question of experience is always the question of judgment-is the medical one, the only model that allows experience to speak for itself [...]." 53 This notion is highly relevant since in the "Apologie" Montaigne makes explicit comments on the suspension of judgment as a means of achieving Ataraxia-imperturbability, mental repose, or quietude-, the principal aim of thought for those adhering to Pyrrhonian skepticism:

Or cette assiette de leur jugement, droicte et inflexible, recevant tous objects sans application et consentement, les achemine à leur Ataraxie, qui est une condition de vie paisible, rassise, exempte des agitations que nous recevons par l'impression de l'opinion et science que nous pensons avoir des choses. D'où naissent la crainte, l'avarice, l'envie, les desirs immoderez, l'ambition, l'orgueil, la superstition, l'amour 
110 SCOTT D. JUALL

de nouvelleté, la rebellion, le desobeissance, l'opiniatreté et la pluspart de maux corporels. Voire s'ils s'exemptent par là de la jalousie de leur discipline. Car ils debattent d'une bien molle façon. Ils ne craignent point la revenche à leur dispute. ${ }^{54}$

However, Montaigne is incapable of reaching a state of Ataraxia, since the memory of La Boétie is one that is inescapably "pénible." 55 Solitude, physical pain and suffering, and the act of writing force Montaigne to lose his ability to employ "jugement" to attain a state of mental tranquility as he recalls his lack of contact and communication with La Boétie, the latter's permanent absence in death, and the traveller's continuing state of isolation. ${ }^{6}$ Such observations remind us that Montaigne is highly aware that he develops his thinking as he writes, since his text depicts his thoughts as they emerge. Writing for Montaigne is therefore the direct product of rethinking his open wounds - mental and physical — and attempting to heal them.

\section{Meditations on worsening health: Montaigne's cogito}

It is when Montaigne's "pensements" turn from the topic of La Boétie's death to his own mortality that we see a kind of thinking that is perhaps closer to a unified Cartesian subject. Montaigne endures one of his most painful health crises on August 24, 1581 during his second stay in La Villa. For an excruciatingly lengthy ten-day period of isolation and severe suffering, the passing of a kidney stone is accompanied by stomach pains, headache, and toothache. Montaigne's suffering is so intense that he can scarcely bear it, and the experience leads him to make a serious consideration of his seemingly imminent death, and the means of facing it:

\footnotetext{
Il y auroit de foiblesse et de lâcheté de ma part, si, certain de me retrouver toujours dans le cas de périr de cette maniere, et la mort s'approchant d'ailleurs à tous les instans, je ne faisois pas mes efforts, avant d'en être là, pour pouvoir la supporter sans peine, quand le moment sera venu. Car enfin la raison nous recommande de recevoir joyeusement le bien qu'il plaît à Dieu de nous envoyer. Or, le seul remede, la seule regle et l'unique science, pour éviter tous les maux qui assiegent l'homme de toutes parts et à toute heure, quels qu'ils soient, c'est de se résoudre à les souffrir humainement, ou à les terminer courageusement et promptement..$^{57}$
}

This journal entry reveals much about Montaigne's philosophy of death-and also that of life. ${ }^{8}$ By pushing medical skepticism to the limit - by exhausting all possible treatments for his suffering-Montaigne seems to be confronted with a truth that he can not doubt in any conceivable manner. He states that the only solution to such a painful situation - emphasized with a repetition of unity: "le seul remede, la seule regle et l'unique science" - is to suffer one's illnesses humanely and appreciate 
what good God has joyously given to humans, or to commit suicide. Montaigne recognizes that death is the only event which can bring an end to suffering and, by extension, to thinking, writing, and life. Teetering on the boundary between life and death, Montaigne deeply contemplates his options, and he chooses to remain alive and continue treating his illness until his death.

Montaigne's sustained focus on his health, a heightened awareness of suffering from a chronic disease, a never-ending quest for treatments, and an intense dwelling on suffering his pain while putting off death seem to suggest a certainty that he exists. Indeed, "avant d'en être là" must imply an "être ici"—an ontological observation made during a conspicuous crystallization of his thought which indicates that Montaigne's thinking is heading towards a sort of Cartesian cogito that he methodically develops as a direct outgrowth of his medical skepticism. However, while Descartes' conception of the self put forth by the cogito, as formulated in his foundational metaphysical works, focuses exclusively on the mind as a thinking entity, Montaigne's conception of the subject concentrates on both mind and body and the intricate interactions between them. Ailing and thinking together confirm Montaigne's existence-precisely because of the corporeal limits of the body. Johnson argues similarly by stating, "In Descartes, the experience proper to the cogito is thought, je pense, donc je suis. Only thought is essential and immediately proper to the subject. Montaigne appears to argue otherwise, claiming instead that the only experience unique to any subject is that of one's own body" in its dynamic interactions with the mind. 59

\section{Montaigne's rewritten theory of medical skepticism in 1582}

Montaigne remains at La Villa until September 7, 1581, when he receives a letter announcing that the jurats of Bordeaux have elected him mayor of the city, after which he almost immediately packs his belongings and heads for home ${ }^{60} \mathrm{His}$ ob-

servations on health all but entirely cease to appear once he emerges from periods of isolation in La Villa, and the remainder of the text generally returns to the excursive descriptions recorded in entries prior to his visit to the Italian spa town. Nevertheless, the experiences with medicine in La Villa are neither lost nor forgotten, since Montaigne has consciously kept a thorough record of his medical experiments in the Journal de voyage. The implications of this record of health are most remarkable when we consider how Montaigne puts these observations to use once he returns from his travels. 
As Montaigne states himself on a number of occasions in the Essais, he rarely deletes from the text but rather frequently joins additional remarks to a work in successive editions. One such declaration - and a highly ironic one as we shall see-is found in "De la ressemblance" itself, where the essayists maintains that, "Au demeurant, je ne corrige point mes premieres imaginations par les secondes; ouy à l'aventure quelque mot, mais pour diversifier, non pour oster. Je veux representer le progrez de mes humeurs, et qu'on voye cháque piece en sa naissance." ${ }^{11}$ The numerous additions to the text of the Essais that transform the work in a number of ways-by developing ideas, refuting them, or by adding apparent digressions to the textual advance-reflect the multiple, changing perspectives and discontinuous narrative structure that critics have long observed in Montaigne's major work. In this connection, Melehy argues that the fact that Montaigne adds so frequently to his text in successive editions is a sure sign of a pre-Cartesian lack of a single, substantial referent and that consequently "there will be no increased homogeneity of the substance of author and the book, no totalizing unification," 62 as the multiple and transforming "je" constantly view and state observations from different, inconstant, mutating perspectives. Melehy observes of the relationship between Montaigne's additions to the Essais in successive editions and the writer's constantly dispersed and resituated subjectivity:

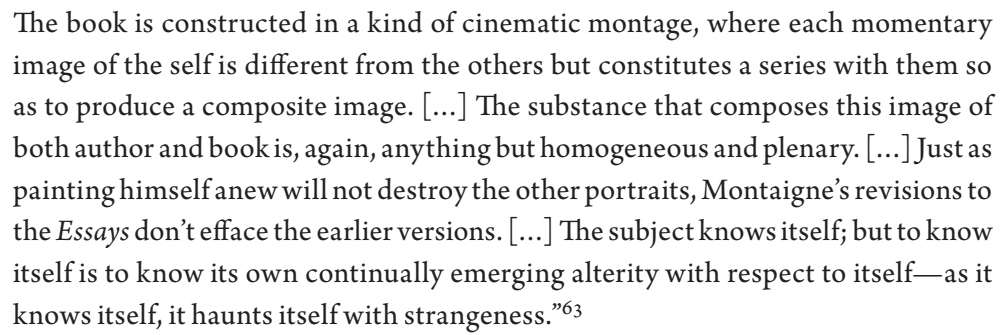

As such, criticism generally contends that the process of textual composition in Montaigne's Essais is quite different from systematic Cartesian thinking and writing. Montaigne's writing his emerging thoughts, and frequently adding to his text as new thoughts surface, are precisely what keep him from attaining the status of a truly modern subject of the likes of Descartes.

The second edition of the Essais, which Montaigne published in 1582, presents a striking exception to this observation. Although Montaigne makes few changes to the first edition as a whole, he makes some startling revisions to his observations on health and medical skepticism precisely in "De la ressemblance." Moreover, it is highly significant that in the second version of this particular essay, instead of simply 
adding to his narrative, Montaigne rewrites and replaces a great amount of text - what amounts to nearly four entire pages in the 1582 edition of the Essais. ${ }^{64}$ Immediately upon returning to the château de Montaigne in the months following his travels, the essayist corrects his earlier observations on medical skepticism described in "De la ressemblance" with information that he gathered at "bains" in the field"notamment ceux della Villa desquels j'ay usé plus souvent \& à diverses saisons." 65 As opposed to putting his thoughts down as they arrive into his mind, Montaigne thus reconsiders and rewrites his earlier theory of medicine based retrospectively on his experiences primarily in La Villa. He depicts therefore more refined observations that reconceive more summarily his statements on health and well-being. By rethinking and rewriting his observations, Montaigne's narrative here reflects what Albert Thibaudet remarks about Cartesian thinking when the seventeenth-century philosopher wrote Discours de la méthode: "Even though Descartes has been a traveler, his thoughts are those of a man who is seated and at rest." 66

In the revised version of "De la ressemblance," Montaigne's corrected theory of medicine reflects an even more heightened sense of skepticism and uncertainty in medical practice. The updated essay describes a much clearer articulation of the notion that each individual requires a unique treatment to cure an illness. Moreover, Montaigne presents a much harsher critique of doctors by presenting a litany of contradictory and antithetical medical recommendations that they provide to patients:

Il est bon de se beigner aux eaux chaudes, d'autant que cela relache \& amollit les lieux, ou se croupit le sable \& la pierre. Mauvais aussi est il d'autant que ceste application de chaleur externe aide les reins a cuire, durcir, \& petrifier la matiere qui y est disposée. A ceux qui sont aux beins, il est plus salubre de manger peu le soir: affin que le breuvage des eaux qu'ils ont a prandre l'endemain matin, face plus d'operation rancontrant l'estomac vuide, \& non empetré. Au rebours, il est meilleur de manger peu au disner, pour ne troubler l'operation de l'eau, qui n'est pas encore parfaite, \& ne charger l'estomac si soudain, apres c'est autre travail \& pour laisser l'office de digerer a la nuict, qui le sçait mieux faire que ne faict le jour, ou le corps \& l'esprit sont en perpetuel mouvemant \& action. Voila commant ils [les médecins] vont bastelant, \& baguenaudant à nos dépens en tous leurs discours. Et ne me sçauroient fournir proposition à laquelle je n'en rebatisse une contraire de pareille force. ${ }^{67}$

Montaigne indicates that his observations are based on categorical testing and refusal of every proposition of medical doctrine through a method of systematic doubt. He relates this notion to an exceedingly direct statement of skepticism in relation to medicine that summarizes his observations made at a number of baths during his recent travels: 
J'ay veu, par occasion de mes voïages, quasi tous les beins fameux de Chrestienté [...]. Et encores que je n'y aye apperceu nul estait extraordinaire \& miraculeux: ains que, m'en informant un peu plus curieusement qu'il ne se faict, j'aye trouvé mal fondez, \& faux tous les bruis de telles operations, qui se sement en ces lieux la \& qui s'y croient (comme le monde va se pipant ayséement de ce qu'il desire). ${ }^{68}$

Such an observation is stunningly analogous to the orderly retrospective approach to writing skepticism that Descartes undertakes nearly 60 years later in Discours de la méthode. Descartes recalls his travels and the importance of solitude in establishing his philosophical thought by stating:

J'étais alors en Allemagne, où l'occasion des guerres qui n'y sont pas encore finies m'avait appelé; et comme je retournais du couronnement de l'empereur vers l'armée, le commencement de l'hiver m'arrêta en un quartier où, ne trouvant aucune conversation qui me divertît, et n'ayant d'ailleurs, par bonheur, aucuns soins ni passions qui me troublassent, je demeurais tout le jour enfermé seul dans un poêle, où j'avais tout loisir de m'entretenir de mes pensées. ${ }^{69}$

As in Cartesian philosophy, which stresses the necessity for achieving perfection through unity, ${ }^{7 \circ}$ Montaigne, in the corrected version of "De la ressemblance," responds to the utterly overwhelming diversity of approaches to practising medicine in his skeptical trials of possible cures by reducing their number, one by one, in a search for certainty. While Montaigne remarks that each nation may have its own opinions concerning the use of waters, he concludes by making an ultimate statement of skepticism regarding the medicine that he tested—and all medicine, for that matter:

Chaque nation a des opinions particulieres, touchant leur usage, \& des loix \& formes de s'en servir toutes diverses: \& selon mon experience l'effect quasi pareil. [...] Voila commant ceste partie de medecine, a laquelle seule je me suis adonné, quoy qu'elle soit la moins artificielle, si a elle sa bonne part de la confusion $\&$ incertitude, qui se voit par tout ailleurs en cest'art. ${ }^{1}$

The addition to the revised 1582 edition of "De la ressemblance" thus ends on the idea that medicine for Montaigne is less a science than an art—an idea to which he refers repeatedly in the essay. ${ }^{72}$ This is perfectly logical, since the Aristotelian definition of art, as Céard reminds us, maintains that its principle resides in the artist himself.73 Indeed, Montaigne is a sufferer who attempts to heal himself; the ultimate kind of empiricism in the medical domain is therefore undertaken by testing treatments autonomously on oneself.

The rewritten portion of "De la ressemblance" therefore reinforces all the more strongly what Montaigne stated in the earlier version of the essay: that he wants 
to substitute all medical doctrines with both a strong emphasis on empiricism and a categorical refusal of existing doctrines-what Céard calls a kind of doctrine in its own right. ${ }^{74}$ However, the empiricism that Montaigne recommends is not in the reach of everyone. He distinguishes between doctors taught by methodical experimentation and observation-those whose proofs "se tirent des choses qui, pour autre consideration, tombent souvent en notre usage" —on the one hand, and those that result "des autres experiences à quoy ils disent avoir esté conduis par la fortune et n'avoir eu autre guide que le hazard," 75 on the other. As noted earlier, Montaigne states repeatedly in the essay that one's own "jugement" is necessary in assessing experience, and that few doctors_or patients_are capable of attaining this judgment. While Montaigne may not introduce a precise method of medical examination per se, he presents nonetheless a model for others to follow in discovering their own empirical method. In this sense, Montaigne's method strongly anticipates what Descartes proposes to his readers in Discours de la méthode: "Ainsi mon dessein n'est pas d'enseigner ici la méthode que chacun doit suivre pour bien conduire sa raison, mais seulement de faire voir en quelle sorte j'ai tâché de conduire la mienne." 76

\section{Textual healings and endings}

The act of writing formerly led Montaigne to open up painful mental wounds in his meditations on the death of La Boétie and his own acute illness-wounds that he tried to heal, however unsuccessfully, through additional meditation and writing. However, by revising previous statements on a suffering self that were incomplete in the first version of "De la ressemblance," Montaigne succeeds in writing a kind of remedy-for both himself and his text. Through this therapeutic procedure, Montaigne therefore reconsiders his thoughts and heals the wounds of the essay, so to speak, in its initial form. ${ }^{77}$ While Montaigne's thought might not be as globally systematic as that of Descartes, his revised statements nonetheless approach a more exhaustive, conclusive formulation of his method of finding certainty. Montaigne's deliberate reformulation and reordering of "De la resemblance" thus refute what theorists of the essayist's poetics have long argued: that one of the defining characteristics of the diegetic advance in the texts comprising the Essais is the absence of a definite end or goal..$^{8}$ Indeed, the new version of "De la ressemblance" reaches more closely toward what Melehy considers one of the principal elements of the earliest example of modern subjectivity in print: the "retrospectively teleological construction of Descartes's autobiography," a history with a "fixed route, metaphysic- 
ally fixed within the terms and boundaries of the subject" that attempts to "arrive at the point of distinguishing clearly 'the true from the false."'79

Nevertheless, the telos of the lengthy rewritten portion of "De la ressemblance" is not the end of the essay. In both the 1580 and 1582 editions of the Essais, Montaigne closes essay II, 37 with a long statement linking personal opinion to practices of contemporary medicine. Because of the variety of perspectives related to medical treatment and the fact that others employ judgment so differently from Montaigne, there necessarily remains an immense degree of uncertainty in medicine. While Montaigne has arrived at a certain method for testing medicinal cures, the field remains widely open for debate and discussion:

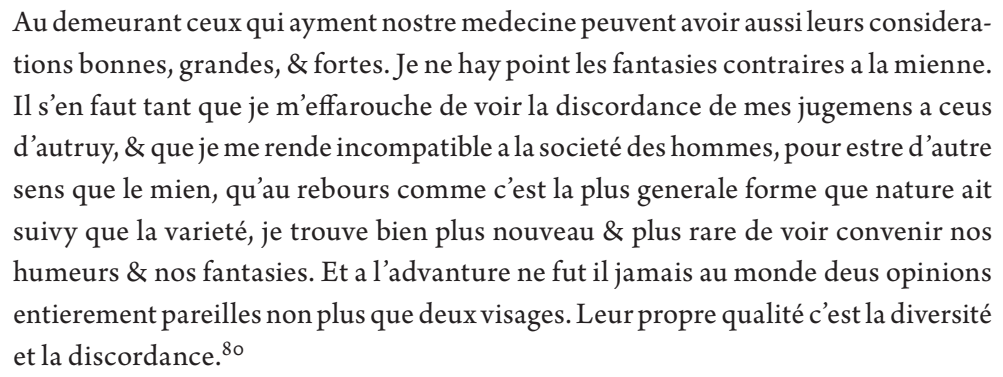

The final words of the essay, which represent two key concepts underlying Montaigne's skepticism, thus leave the essay on a diegetic threshold rendered all the more complex by their open qualities. The terms "la diversité et la discordance" recall central characteristics of Montaigne's open, digressive, non-teleological writing as a whole throughout the essays. In the first two editions of the Essais, there is consequently a tension between a definitive closure-the textual end of the essay-and an opening up of hermeneutic approaches and concepts—diversity and discordance of opinion. This observation is particularly pertinent when we consider that these words bring the first two published editions of the Essais to their "Fin," since "De la ressemblance" is the last essay of the two books that comprise the Essais published in 1580 and $1582 .{ }^{81}$ Since diversity and discordance are precisely what Montaigne aims to conquer in his methodical medical trials, they reflect a consciousness of the body's role in striving for a systematic method of finding certainty and unity of thought. From this perspective, a consideration of Montaigne's corporeal experiences while travelling — and particularly during his stays in La Villa—sheds new light on the role of the essayist's sense of self and being in the foundation of modern subjectivity. ${ }^{82}$ 


\section{Conclusion: Montaigne's meta-Cartesian legacy}

The philosophical canon has long privileged the systematic thought of Descartes as the kind of thinking that modernity would attempt to master. While the passages on medical treatment in Montaigne's Journal de voyage anticipate a Cartesian method for establishing certainty, the text presents the record of a dynamic person in the process of constructing his subjectivity through suffering and empirical skepticism—not a static, fixed system of thought. In the lengthy rewritten portion of "De la ressemblance," however, Montaigne approaches more closely the unified subjectivity of Descartes, who drew on his past learning, travels, and experiences of solitude in the poêle in order to find fundamental and indubitable truths and then create an ordered narrative recounting the process. It is therefore precisely the relationship between Montaigne's experiences of solitude and suffering in La Villa, his developing skepticism, and the greatly revised essay "De la ressemblance" that represents his most integral, self-contained unity as a writing subject. Montaigne's concept of the subject produced by and through writing in La Villa and in essay II, 37 thus contributes to a significant shift of systems - one that sets up ever more strongly an argument for the autonomous "I" as an ontological possibility before Decartes' visit to the poêle.

On the one hand, then, Montaigne's concept of subjectivity is much more similar to that of Descartes than has previously been argued. On the other hand, Montaigne's sense of the self remains uniquely his own, since it accounts for the dynamic interaction between the subjective mind and the body. Montaigne's "je" therefore reflects his own unique brand of subjectivity - precisely because of the great degree to which his concept of ontology is linked directly to a consideration of the relationship between the body, suffering (physical and mental), and skepticism. Montaigne's concept of subjectivity is therefore quite distinct from that written in Descartes' early metaphysical texts, which refrain from considering such a discussion of the body and the corporeal dimensions of being. Yet as Erec R. Koch argues, Descartes, as Montaigne before him, would conceive of the role of interactions between body and mind-particularly the manner in which they relate to the individual's ethical place and comportment in society-in reconsidering subjectivity much later than in his earliest texts on metaphysics. ${ }^{83}$ I contend that the delay in Descartes' arriving at this understanding may very well reside precisely in the extent of Montaigne's influence on Cartesian thinking. While theorists such as Georges Van Den Abbeele and Melehy remark that Descartes drew heavily from Montaigne's Essais in formulating his philosophical position in his earliest meta- 
118 SCOTT D. JUALL

physical works, ${ }^{84}$ I would like to emphasize the fact that the seventeenth-century philosopher could not have been influenced by Montaigne's thought in the Journal de voyage, since the travel narrative remained undiscovered until 1770 and was not published until four years later. ${ }^{85}$ It took therefore many years of additional experience, thinking, and writing for Descartes to move beyond mind/body dualism in order to recognize the strong link between mind and body in his reformulations of ontology and subjectivity. In a sense, then, Montaigne was one half century ahead of his seventeenth-century compatriot in developing this essential component of modern philosophical thought.

As Popkin has maintained for some 45 years, skepticism — especially Pyrrhonian skepticism - played a crucial role in the arguments that led to the formulation of what we now call "modern philosophy." 86 A study of Montaigne's solitude, skepticism, and subjectivity in the Journal de voyage and certain essays treating the immediate and dynamic interaction between mind and body therefore reveals a wellspring of important observations on the development of early modern philosophical thought. Conclusions drawn from such an analysis should encourage readers to turn their focus to the essayist turned traveller as a model of subjectivity that is perhaps more relevant to today's individual than what Zahi Zalloua has termed "the hegemony of Cartesian thought." ${ }^{87}$ Montaigne's works are thus as insightful about the dimensions of early modern metaphysics, ontology, and subjectivity as they are relevant for considering the postmodern subject. Montaigne's proto-Cartesian subjectivity-what may now be considered, I contend, a sort of meta-Cartesian subjectivity-provides us with all the more justification to consider the essayist's, and traveller's, approaches to writing the self as the point of departure for the foundation of modern thought produced by France's first modern philosopher.

\section{Notes}

I would like to acknowledge generous support from the Charles L. Cahill Award at the University of North Carolina Wilmington, which funded much of the research for this article; I am grateful to the faculty and staff at the University of Virginia Special Collections Library in Charlottesville for their kind and helpful assistance during a period of research there. I also thank two anonymous readers from the journal for their valuable comments on an earlier version of this paper.

1. Melehy's detailed analysis of the beginnings of the modern subject in canonical works by Montaigne and Descartes is highly crucial to the development of my argument here. His study provides a thorough comparison of subjectivity and ontology in Montaigne's Essais and Descartes' Discours de la méthode and Méditations métaphy- 
siques. See Hassan Melehy, Writing Cogito: Montaigne, Descartes, and the Institution of the Modern Subject (Albany: State University of New York Press, 1998). Richard Henry Popkin's classic study of the historical development of skepticism provides a much broader yet more indirect comparison of subjectivity through an analysis of skeptical thought in early modern Europe. See Popkin, The History of Scepticism from Savonarola to Bayle (Revised and expanded, Oxford: Oxford University Press, 2003 [1979]). While both theorists analyze subjectivity in Montaigne's Essais, neither considers the relationship between Montaigne's medical treatments, his theories of medical skepticism during his periods of solitude in La Villa, and subjectivity; nor do they treat either Montaigne's Journal de voyage or his experiences while travelling.

2. Melehy, pp. 21 and 51 , respectively.

3. Melehy, pp. 9 and 103, respectively. Melehy also states that "With Descartes the task of philosophy becomes to teach in a way that produces an autonomous subject, man as epistemic master: man becomes subject through the ascendancy of reason [...]" See Melehy, p. 11. François Paré argues similarly through an analysis of the notion of Montaigne and Descartes as autobiographers; he concludes that since Descartes institutes a single, unified representation of the autobiographical subject, his is a reductive autobiography. By contrast, since Montaigne portrays himself as multiple "je," his autobiography is productive and, as a result, he reveals a much less concrete portrait of the autobiographical self. See Paré, "Descartes et Montaigne, autobiographes," Etudes littéraires 17.2 (automne 1984), pp. 381-94.

4. Andrea Carlino describes the influence of Petrarch's antimedical treatise Invectum contra medicum and Henricus Cornelius Agrippa von Nettescheim's critique of medicine De incertitudine et vanitate scientiarum (1530) on early modern medical theorists such as Montaigne, although he does not mention the latter's experiences with medicine while travelling. See Carlino, "Petrarch and the Early Modern Critics of Medicine," The Journal of Medieval and Early Modern Studies 35.3 (Fall 2005), pp. 559-82. A number of other theorists provide perspectives on Montaigne's experiences with medicine that are pertinent to my analysis, although none has been published recently. J.-P. Pitton provides a general overview of medical skepticism in early modern Europe. See Pitton, "Scepticism and Medicine in the Renaissance," in Scepticism from the Renaissance to the Enlightenment, ed. Richard Henry Popkin and Charles B. Schmitt (Wiesbaden: Harrassowitz, 1987), pp. 103-32. Margaret Brunyate situates Montaigne's use of medicine in the historical context of the development of science as well as some classical influences on his medical beliefs and practices. See Brunyate, "Montaigne and Medicine," in Montaigne and His Age, ed. Keith Cameron (Exeter: University of Exeter Press 1981), pp. 27-38. François Batisse concisely describes the relationship between metaphysics, science, and medical empiricism in Montaigne's Journal de voyage. See Batisse, "Montaigne et les principes de la médecine expérimentale," in Mémorial du 1er Congrès International des Etudes Montaignistes, ed. Georges Pallassie (Bordeaux: Taffard, 1964), pp. 204-14. Batisse also provides a very thorough 
but mostly uncritical book-length study of Montaigne's experiences with medicine. See Batisse, Montaigne et la médecine (Paris: Belles Lettres, 1962).

5. Popkin's work provides the most comprehensive study of skepticism by outlining the role of Ancient skeptics in the intellectual crisis of the Reformation and its influence on Western thought throughout early modernity. His comparative approach is highly practical for grasping the broad developments of skeptical thought during the period. Frédéric Brahami's thorough and detailed analyses of Montaigne's skepticism through close readings of both the Essais and Journal de voyage are highly useful to my study. See Brahami, Le Scepticisme de Montaigne (Paris: Presses Universitaires de France, 1997). For a broader comparative study of skepticism in early modern Europe, see Brahami, Le travail du scepticisme: Montaigne, Bale, Hume (Paris: Presses Universitaires de France, 2001). Ann Hartle's recent study of Montaigne's skepticism, a highly original analysis of the topic, is particularly insightful and rich in its treatment of Montaigne as a deeply unique philosopher who displays both skeptical and non-skeptical approaches to interpreting phenomena. See Hartle, "Montaigne and Skepticism," in The Cambridge Companion to Montaigne, ed. Ullrich Langer (Cambridge: Cambridge University Press, 2005), pp. 183-206.

6. Sextus Empiricus's ancient work on Pyrrhonism is the main source of Pyrrhos's thought. See Sextus Empiricus, Outlines of Pyrrhonism, trans. R.G. Bury (Buffalo: Prometheus, 1990). Three recent studies provide useful perspectives on the transmission of Pyrrho's thought in Europe since Antiquity: Luciano Floridi, Sextus Empiricus: The Transmission and Recovery of Pyrrhonism (Oxford: Oxford University Press, 2002); Walter Sinot-Armstrong, ed., Pyrrhonian Skepticism (Oxford: Oxford University Press, 2004); and Richard Bett, Pyrrho: His Antecedents and His Legacy (Oxford: Oxford University Press, 2003). Floridi also provides important analyses of the influence of Sextus Empiricus's writings on Pyrrhonism in the Renaissance. See Floridi, “The Diffusion of Sextus Empiricus's Works in the Renaissance," Journal of the History of Ideas 56 (1995), pp. 63-85. Terence Cave's recent study of the impact of Sextus Empiricus in sixteenth-century French literature and culture provides exemplary readings of the role of skepticism in the development of early modern French literature. See Terence Cave, Pré-histoires: Textes troublés au seuil de la modernité (Genève: Droz, 1999).

7. For Montaigne's comments on medicine in the "Apologie," see in particular Montaigne, Essais, ed. Pierre Villey (Paris: Presses Universitaires de France, 1988 [1965]), pp. 491-92. I examined a copy of the first edition of Montaigne's Essais (Bordeaux: S. Millanges, 1580) at the Newberry Library in Chicago, Illinois, as well as a copy of the second edition of Montaigne's Essais (Bordeaux, S. Millanges, 1582) at the University of Virginia Special Collections Library in Charlottesville, Virginia. I cite the 1580 and 1582 editions only where the uniqueness of each edition is relevant; in all other cases, I cite Pierre Villey's modern critical edition of the Essais.

8. For Popkin's discussion of the three forms of skeptical crises that troubled early modern intellectuals, see Popkin, The History of Scepticism, p. 55 . 
9. Carlino, p. 571.

10. Montaigne, Essais, ed. Villey, pp. 771-72. Also see Carlino, pp. 571-72.

11. Jean Céard analyzes the important influence of early modern Italian medicine on the development of Montaigne's medical hypotheses. See Céard, "Contributions italiennes aux mutations de la médecine selon Montaigne," Montaigne e l'Italia: Atti del Congresso internazionale di Studi, Milano-Lecco, 26-30 ottobre 1988, ed. E. Balmas (Genève: Slatkine, 1991), pp. 229-43.

12. Montaigne, Essais, ed. Villey, p. 767.

13. Montaigne, Essais, ed. Villey, p. 764.

14. Montaigne, Essais, ed. Villey, p. 764. For additional descriptions of the role of Montaigne's individual, autonomous experiences in seeking medical treatment, see Montaigne, Essais, ed. Villey, pp. 765, 766, 781, 782, and 790.

15. Montaigne, Essais, ed. Villey, pp. 760-61, my emphasis.

16. Carlino, p. 571.

17. Carlino, p. 573 .

18. While Montaigne visits spas throughout Lorraine, Switzerland, and Italy, his most prolonged and concentrated focus on treatment at baths occurs in La Villa, a small town in Tuscany. Montaigne visits this bathing centre twice; May 7-June 21, 1585 and August 14-September 12, 1581, travelling through Italian cities in the region between these two stays. See Montaigne, Journal de voyage, ed. François Rigolot (Paris: Presses Universitaires de France, 1992), pp. 156-204; also see pp. 235-77 for the French translation of the portion of the Journal de voyage written in Italian. I have consulted a copy of the first edition of Montaigne's travel journal, Journal de voyage de Michel de Montaigne en Italie, Par la Suisse \& l'Allemagne, en 1580 \& 1581, Avec des Notes par M. de Querlon (Rome and Paris: Le Jay, 1774), an A edition, in-4 $4^{\circ}$, en 1 volume which is located at the University of Virginia Special Collections Library in Charlottesville, Virginia. Owing to the lack of accessibility of this early edition, I have chosen to cite the first edition only where relevant to my argument; in all other cases, I cite Rigolot's modern edition.

19. Montaigne, Journal de voyage, ed. Rigolot, p. 156.

20. While the first stay took place before the arrival of the seasonal bathing visitors who customarily arrived in June and stayed until September, Montaigne's second visit takes place during the busy season of visitors to the spa town. See Montaigne, Journal de voyage, ed. Rigolot, p. 157.

21. On February 16, 1581, Montaigne takes over from his secretary, whom he had dismissed in Rome, and writes the remainder of the Journal de Voyage himself. See Montaigne, Journal de voyage, ed. Rigolot, p. 109.

22. George Hoffmann, Montaigne's Career (Oxford: Clarendon Press, 1998), p. 15.

23. In "De la vanité" (III, 9), Montaigne would later justify his travels by asserting his distaste for governing his estate and his impatience related to "servitudes domestiques" and his half-heartedness for "devoirs de l'amitié maritale.” See Montaigne, Essais, ed. Villey, p. 975 . 
24. Rigolot, Introduction to Montaigne, Journal de voyage, ed. Rigolot, p. xxiii.

25. Milon, "L'Écriture d'Artaud est sa souffrance: le refus de tout psychologisme," L'Esprit Créateur 45.3 (Fall 2005), pp. 7-17 (p. 9).

26. Montaigne, Journal de voyage, ed. Rigolot, pp. 159-6o.

27. Céard, p. 240.

28. Melehy, p. 48.

29. Melehy, p. 104.

30. R. Dujarric de la Rivière analyzes some key experiences of medical treatment in the Journal de voyage to support his theory that Montaigne is a precursor to modern scientific methodology. See Dujarric de la Rivière, "Montaigne et la médecine," Bulletin de la Société des Amis de Montaigne 27 (1963), pp. 3-17. For a stimulating discussion of the concept of science in the Renaissance and the lack of a precise experimental methodology, see George Pholien, “Montaigne et la science," Bulletin de la Société des Amis de Montaigne 19-20 (Jan-June 1990), pp. 61-70.

31. Popkin, The History of Scepticism, pp. 150-51.

32. Montaigne, Essais, ed. Villey, p. 771.

33. Montaigne, Journal de voyage, ed. Rigolot, p. 162.

34. Montaigne, Journal de voyage, ed. Rigolot, p. 163.

35. Montaigne, Journal de voyage, ed. Rigolot, p. 162.

36. Montaigne, Journal de voyage, ed. Rigolot, p. 163.

37. Montaigne, Journal de voyage, ed. Rigolot, p. 162.

38. Montaigne, Journal de voyage, ed. Rigolot, pp. 178 and 247.

39. Melehy, p. 100.

40. Montaigne, Journal de voyage, ed. Rigolot, pp. 174 and 242.

41. Frédéric Brahami analyzes this aspect of Montaigne's theory of medical skepticism, stating: "En tant que théorie, [la médicine] hérite de tous les défauts liés aux systèmes de représentation. Figure achevée du dogmatisme, elle excelle dans l'abstraction, c'est-à-dire dans l'arbitraire. Elle construit un modèle général du corps qui ne peut que manquer son objet, parce que chaque corps est singulier, non seulement d'un point de vue strictement matériel, mais en ce que la physiologie est elle-même un effet singulier des habitudes de chacun.” See Brahami, Le Scepticisme de Montaigne (Paris: Presses Universitaires de France, 1997), p. 93.

42. See Donald Frame, Montaigne: A Biography (New York: Harcourt, Brace \& World, 1965), p. 222.

43. Timothy Hampton, "The Subject of America: History and Alterity in Montaigne's 'Des coches',' in Writing from History: The Rhetoric of Exemplarity in Renaissance Literature (Ithaca: Cornell University Press, 1990), pp. 80-103 (p. 92).

44. Theorists such as Melehy often identify the modern period as beginning with Descartes or between Montaigne and Descartes. See Melehy, esp. chapter 1.

45. See "Apologie," Montaigne, Essais, ed. Villey, p. 491 and "De la ressemblance," Montaigne, Essais, ed. Villey, pp. 759-60. 
46. Stephen Toulmin, Cosmopolis: The Hidden Agenda of Modernity (New York: The Free Press, 1990), esp. pp. 36-42 (p. 37). Toulmin's provocative analysis identifies Montaigne's fundamental place in the beginning of modern subjectivity, precisely because of his emphasis on the interaction between mind and body.

47. Montaigne had met Ossat in Rome while the latter was accompanying Paul de Foix, Archbishop of Toulouse. See Journal de voyage, ed. Rigolot, p. 145.

48. Montaigne, Journal de voyage, ed. Rigolot, p. 162, my emphasis.

49. Montaigne uses the term "pensement" meaning "mental activity" numerous times in all three books of the Essais, of which two instances are particularly revealing. In both "De ne contrefaire le malade" (II, 25) and especially in "De la ressemblance," Montaigne draws an implicit parallel between thinking and treating illness or injury as in the passage in the Journal de voyage. See Montaigne, Essais, ed. Villey, pp. 689 and 773, respectively. Sixteenth-century etymology and orthography of "pensement" support this argument. The term "pensement" first appeared in 1188 as meaning "action de penser de quelque chose; résultat de cette action" while "pensemens" initially appeared in 1531 as "soins donnés à un malade ou à un blessé" — a general treatment for one who is sick or injured. In the tenth century, "exercer son esprit" was spelled "panser" or "penser" while "soigner" was spelled only "penser"- a spelling that remained through the seventeenth century; it was not until the eighteenth century that "to heal or treat a wound" and "to think" assumed definitively the respecive spellings "panser" and "penser" in order to distinguish their meaning. See entries for "pansement," "panser," "pensée," "pensement," and "penser," in Trésor de la langue française, 15 vols. (Paris: Gallimard, 1971-1992).

50. Montaigne explains the misdiagnosis of La Boétie's illness by doctors in "De la ressemblance," stating that "Cependant qu'ils craignent d'arrester le cours d'un dysenterique pour ne luy causer la fiévre, ils me tuarent un amy qui valoit mieux que tout, tant qu'ils sont." See Montaigne, Essais, ed. Villey, p. 774.

51. Milon states, "Lorsque l'écriture est intimement liée à la souffrance de l'écrivain, lorsqu'elle ne calme pas ses anxiétés mais qu'elle les réactive, [...] elle n'est ni un remède ni un traitement; elle est ce qui inscrit la douleur au plus profond du corps pour rappeler à l'auteur qu'il est en surcis. [...] Cette écriture est aussi une mise à jour de sa souffrance dans sa chair que le travail d'écrivain ne saurait apaiser." See Milon, p. 9. This suffering is understandable: by travelling to unknown lands Montaigne hoped to find a "diversité de moeurs" that would transform his ennui and banality of daily life into an "exercitation de l'âme" that "lui faisait cruellement défaut depuis la mort de son ami, Etienne de la Boétie.” See Rigolot, Introduction to Montaigne, Journal de voyage, ed. Rigolot, p. vii.

52. Montaigne, Essais, ed. Villey, pp. 759-6o.

53. Johnson, "Descartes's Corps," Arizona Quarterly 57.1 (Spring 2001), pp. 113-52 (p. 127).

54. Montaigne, Essais, ed. Villey, p. 503. For a useful discussion of ancient Ataraxia, see Bett, pp. 105-11. 
55. One of the earliest readers of the Journal de voyage and its first editor, Meunier de Querlon, comments on the lingering presence of La Boétie in Montaigne's mind in a lengthy note on this passage in the first edition of the work: "Etienne de la Boétie, l'ami le plus intime \& le plus chéri de Montaigne, Auteur du Discours intitulé De la Servitude volontaire. [...] La Boétie étoit mort depuis environ dix-huit ans, (en Août 1563): ce qui fait l'éloge du caractere de Montaigne \& de son illustre ami. L'amitié après la mort n'est donc pas absolument une chimère? Au moins paroît-il que Montaigne étoit capable d'un sentiment qu'on regarde volontiers comme romanesque, parce qu'en effet, il est bien rare qu'il subsiste encore, ou qu'il existe long-temps, quand l'objet qui l'a produit n'est plus. Seroit-ce que dans les ames d'une certaine trempe, la serie des impressions sensibles s'étend au dela du terme ordinaire: comme dans un membre coupé on sent quelquefois une douleur locale qui n'existe que dans le cerveau, puisque le membre n'est plus, \& que l'on pourroit appeler une réminiscence physique?" See Montaigne, Journal du voyage de Michel de Montaigne en Italie, Par la Suisse \& l'Allemagne, en 1580 \& 1581, Avec des Notes par M. de Querlon (Rome and Paris: Le Jay, 1774), p. 218 , note 6.

56. Montaigne later laments his solitude and the absence of worthy travel companions during his voyage in "De la vanité" (III, 9): "C'est une rare fortune, mais de soulagement inestimable, d'avoir un honneste homme, d'entendement ferme et de meurs conforme aux vostres, qui ayme à vous suyvre. J'en ay eu faute extreme en tous mes voyages.” See Montaigne, Essais, ed. Villey, p. 986. Rigolot maintains that Montaigne thinks here of La Boétie—a “compagnon de voyage idéal.” See Rigolot, Introduction to Montaigne, Journal de voyage, ed. Rigolot, p. ix.

57. Montaigne, Journal de voyage, ed. Rigolot, p. 272, my emphasis. For the passage in its original Italian, see Montaigne, Journal de voyage, ed. Rigolot, pp. 199-200.

58. For a study of Montaigne's confrontation of death through writing in the Essais, see Dorothea B. Heitsch, "Approaching Death by Writing: Montaigne's Essais and the Literature of Consolation,” Literature and Medicine 19.1 (Spring 2000), pp. 96-106.

59. Johnson, p. 127.

60. Montaigne, Journal de voyage, pp. 202 and 275.

61. Montaigne, Essais, ed. Villey, p. 758.

62. Melehy, p. 68.

63. Melehy, p 67-68.

64. Montaigne, Essais, 1582, pp. 789-93; also see Montaigne, Essais, ed. Villey, pp. 775-77.

65. Montaigne, Essais, 1582, p. 791; also see Montaigne, Essais, ed. Villey, p. 777.

66. Albert Thibaudet, Montaigne, ed. Floyd Gray (Paris: Gallimard, 1963), p. 166.

67. Montaigne, Essais, 1582, pp. 789-90; also see Montaigne, Essais, ed. Villey, pp. $775-76$.

68. Montaigne, Essais, 1582, pp. 790-91; also see Montaigne, Essais, ed. Villey, pp. $776-77$. 
69. Descartes, Discours de la méthode, ed. George Heffernan (Notre Dame: University of Notre Dame Press, 1994), p. 26. He also summarizes his nine years of subsequent travel and the eight years of focused study that led to his writing Discours de la méthode in Holland. See Descartes, Discours de la méthode, pp. 46-50.

70. Descartes states: "Entre lesquelles [mes pensées], l'une des premières fut que je m'avisai de considérer que souvent il n'y a pas tant de perfection dans les ouvrages composés de plusieurs pièces, et faits de la main de divers maîtres, qu'en ceux auxquels un seul a travaillé. Ainsi voit-on que les bâtiments qu'un seul architecte a entrepris et achevés ont coutume d'être plus beaux et mieux ordonnés que ceux que plusieurs ont tâché de raccommoder, en faisant servir de vieilles murailles qui avaient été bâties à d'autres fins. [...]" See Descartes, Discours de la méthode, p. 26.

71. Montaigne, Essais, 1582, pp. 791-92; also see Montaigne, Essais, ed. Villey, p. 777.

72. See, for example, Montaigne, Essais, ed. Villey, pp. 775, 777, and 780.

73. Céard, p. 240.

74. Céard, p. 238.

75. Montaigne, Essais, ed. Villey, p. 782. For a thorough discussion of this notion, see Jean Starobinski, Montaigne en mouvement (Paris: Gallimard, 1982), pp. 169-222.

76. Descartes, Discours de la méthode, p. 16.

77. Fausta Garavini argues that the additions that Montaigne later makes to the Essais function frequently as "pansements." See Garavini, "Allongeails ou pansements? La fonction des ajouts dans le texte de 1588 (A propos de II,11: 'De la cruauté')," Revue d'Histoire Littéraire de la France 88.5 (1988), pp. 908-22.

78. See, for example, Stephen Rendall, “In Disjointed Parts/Par articles décousus," New York Literary Forum 9-10 (1981), pp. 71-83; Rigolot, Les Métamorphoses de Montaigne (Paris: Presses Universitaires de France, 1988), esp. chapter 7; and Edwin Duval, "Lessons of the New World: Design and Meaning in Montaigne's Des Cannibales (I: 31) and Des Coches (III: 6)," Yale French Studies 64 (1983), pp. 95-112.

79. Melehy, p. 104.

8o. Montaigne, Essais, 158o, pp. 649-50 and Montaigne, Essais,1582, p. 806.

81. See Montaigne, Essais, 1580, p. 650 and Montaigne, Essais, 1582, p. 805. In Villey's edition of the Essais, "De la ressemblance" does not end on the term "la discordance." By the 1595 posthumous edition, Montaigne had removed this final term from the end of the essay, bringing it, and the book, to an end on "la diversité" - the precise opposite of Cartesian unity of thought. See Montaigne, Essais, ed. Villey, p. 786.

82. While clearly beyond the scope of this study, it would be useful to consider the idea that Montaigne's experiences of solitude, skepticism, and subjectivity may account, at least in part, for the radically different content, length, and form of the essays in the third book of the Essais - the only essays written in their entirety after his travels.

83. While Descartes' earlier metaphysical writings continue to reinforce a corporeal model of the body founded on "alienation and mechanization," he develops a new theory in his correspondence with Elisabeth of Bohemia and the more systematic Les passions de l'ame, written in 1649, just one year before Descartes died. In these 
126 SCOTT D. JUALL

later texts, Koch argues, Descartes is most concerned with the ethical dimensions of mind-body interactions: "Descartes articulates a new model of the biological body, a model that informs the place of the subject in civil society. The Cartesian body is not the purely mechanical one that is subject to Foucauldian or other coercive dressage. In the Cartesian model, the body is the source and site of passions and sensibility: it is an aesthetic body, an aesthetic machine." See Koch, "Cartesian Corporeality and (Aesth)Ethics,” PMLA 121.2 (March 2006), pp. 405-20 (p. 417).

84. Van Den Abbeele contends that "Descartes was as opposed to [...] the figure-never named-of Montaigne, the refutation of whose work constitutes the principal driving force behind the Cartesian opus.” See Van Den Abbeele, Travel as a Metaphor: from Montaigne to Rousseau (Minneapolis: University of Minnesota Press, 1992), p. 41. Melehy contends that "Much of Montaigne's text turns up in [Descartes'] writing, reworked and refigured, those aspects that would assault the cogito undergoing a repression: one may even see reinscribed, unacknowledged citations, marking precisely what needs to be delimited, subordinated-excluded through an interior confinement-interwoven in Descartes's texts.” See Melehy, p. 7.

85. The first edition of Montaigne's Journal de voyage was published in 1774 . See Montaigne, Journal du voyage de Michel de Montaigne en Italie, Par la Suisse \& l'Allemagne, en 1580 \& 1581, Avec des Notes par M. de Querlon (Rome and Paris: Le Jay, 1774). For a thorough history of the discovery and early publication of the Journal de voyage, see Rigolot's introduction to Montaigne, Journal de voyage, pp. v-vi.

86. Popkin, The History of Scepticism, p. 55.

87. Zalloua, "Montaigne and the Levinasian Other," L'Esprit Créateur 46.1 (Spring 2006), pp. 86-95 (p. 86). 